\title{
ISOVALENCE SUBSTITUTIONS IN MULTICOMPONENT ALUMINATES $\mathrm{ABCO}_{4}$
}

\author{
L. Komissarova, G. Zimina, F. Spiridonov, G. Pushinina \\ Lomonossov Moscow State University, 119899 GSP-3 Moscow, Russia
}

\section{A. Gloubokov and A. Pajączkowska}

Institute of Electronic Material Teclınology, Wólczyńska 133, 01-919 Warsaw, Poland

The crystallochemical characteristics of polycrystalline samples, $\mathrm{Sr}_{1-x} \mathrm{La}_{x} \mathrm{AlO}_{4}, \mathrm{Sr}_{1-x} \mathrm{Nd}_{x} \mathrm{AlO}_{4}(x=0.02 \div 0.20)$ and $\mathrm{Sr}_{1-x} \mathrm{Bi}_{x} \mathrm{NdAlO}_{4}(x=$ $0.05 \div 0.50)$ prepared by the oxalate coprecipitation and cryochemical technique have been investigated. The existence limits of single-phase states for pairs of elements $\mathrm{Sr}-\mathrm{Pb}(x<0.05)$ and $\mathrm{Nd}-\mathrm{Bi}(x<0.2)$ were determined. The microprobe $\mathrm{X}$-ray analysis showed the $\mathrm{Bi}$ uniform distribution. The dielectric properties of pure $\mathrm{SrLaAlO}_{4}, \mathrm{SrLaGaO}_{4}$ and partial replacement $\mathrm{La} \rightarrow \mathrm{Nd}$ samples were measured. It can be concluded that these compounds are suitable as substrate materials of HTSC thin films.

PACS numbers: 77.84.Bw

Preparation of high quality substrate materials for HTSC-films is a subject of numerous investigations of the recent years [1-3]. Complex aluminates and gallates $\mathrm{ABCO}_{4}$-type, where $\mathrm{A}=\mathrm{Sr} ; \mathrm{B}=\mathrm{La}, \mathrm{Nd} ; \mathrm{C}=\mathrm{Al}, \mathrm{Ga}$, are (very perspective for these purposes) suitable substrates for these films.

The present paper deals with results of investigations of crystallochemical characteristics of polycrystalline samples $\mathrm{SrLaAlO}_{4}$ (SLA), $\mathrm{SrNdAlO}_{4}$ (SNA), $\mathrm{SrLaGaO}_{4}$ (SLG) and the products of partial substitutions of $\mathrm{Sr}$ and $\mathrm{La}(\mathrm{Nd})$ by $\mathrm{Pb}$ and $\mathrm{Bi}$. Samples were produced by the oxalate coprecipitation or cryochemical technique.

The phase compositions of the samples were determined by an X-ray analysis and the chemical compositions of some samples were investigated by a local microprobe analysis.

For revealing a possible homogeneity region of SLA compound in a ternary system $\mathrm{SrO}-\mathrm{La}_{2} \mathrm{O}_{3}-\mathrm{Al}_{2} \mathrm{O}_{3}$ samples were synthesized with an excess of initial components (1-2 mol.\%). All final products contain many phases and their lattice parameters did not change. So, we did not detect experimentally the homogeneity region of SLA compound. Thus, the structure of these compounds, probably, has strict dimensional restrictions. The formation of $\mathrm{ABCO}_{4}$-phase for yttrium is impossible what confirms our supposition. We tried to receive $\mathrm{SrBiAlO}_{4}$, although the 
experiments showed that this phase does not exist. Only the mixture of complex aluminates and bismuthates was found after thermal treatments.

Using the above-mentioned methods pure single phase aluminates and gallates as well as doped products were received. We used two different approaches for doped products obtaining: the cation composition conservations $\left(\mathrm{Sr}_{1-x} \mathrm{~Pb}_{x} \mathrm{LaAlO}_{4}\right.$, $\left.\mathrm{Sr}_{1-x} \mathrm{Ba}_{x} \mathrm{NdAlO}_{4}, \mathrm{SrNd}_{1-x} \mathrm{Bi}_{x} \mathrm{AlO}_{4}\right)$ and additions of superstoichiometric or substoichiometric quantities of cations (1-2 mol.\%). Table I represents the final X-ray data. These values are in good agreement with literature data $[4,5]$.

\section{TABLE I}

X-ray data for doped complex aluminates.

\begin{tabular}{l|l|l|l}
\hline \hline \multirow{2}{*}{ Nominal composition } & \multicolumn{3}{|c}{ Lattice parameters } \\
\cline { 2 - 4 } & \multicolumn{1}{|c}{$a[\AA]$} & \multicolumn{1}{c}{$c[\AA]$} & $V\left[\AA^{3}\right]$ \\
\hline $\mathrm{Sr}_{0.98} \mathrm{~Pb}_{0.02} \mathrm{NdAlO}_{4}$ & $3.722(2)$ & $12.48(1)$ & $173.0(3)$ \\
$\mathrm{Sr}_{0.95} \mathrm{~Pb}_{0.05} \mathrm{NdAlO}_{4}$ & $3.722(4)$ & $12.46(2)$ & $173.0(6)$ \\
\hline $\mathrm{Sr}_{0.95} \mathrm{~Pb}_{0.05} \mathrm{LaAlO}_{4}$ & $3.752(3)$ & $12.617(10)$ & $178.0(4)$ \\
$\mathrm{Sr}_{0.9} \mathrm{~Pb}_{0.1} \mathrm{LaAlO}_{4}$ & $3.757(3)$ & $12.626(11)$ & $178.2(4)$ \\
$\mathrm{Sr}_{0.85} \mathrm{~Pb}_{0.15} \mathrm{LaAlO}_{4}$ & $3.759(3)$ & $12.634(10)$ & $178.5(4)$ \\
\hline $\mathrm{SrNd}_{0.95} \mathrm{Bi}_{0.05} \mathrm{AlO}_{4}$ & $3.722(2)$ & $12.48(2)$ & $172.9(5)$ \\
$\mathrm{SrNd}_{0.90} \mathrm{Bi}_{0.10} \mathrm{AlO}_{4}$ & $3.718(3)$ & $12.49(2)$ & $172.7(6)$ \\
\hline $\mathrm{SrLaAlO}_{4}[4]$ & 3.755 & 12.62 & \\
$\mathrm{SrNdAlO}_{4}[5]$ & 3.723 & 12.47 &
\end{tabular}

TABLE II

Local microprobe analysis data.

\begin{tabular}{c|c|c|c|c|c}
\hline \hline \multirow{2}{*}{$\begin{array}{c}\text { Nominal sample } \\
\text { composition }\end{array}$} & Point & \multicolumn{4}{|c}{ Atomic elements relations } \\
\cline { 3 - 6 } & & $\mathrm{Al}$ & $\mathrm{Sr}$ & $\mathrm{Nd}$ & $\mathrm{Bi}$ \\
\hline $\mathrm{SrNd}_{0.9} \mathrm{Bi}_{0.1} \mathrm{AlO}_{4}$ & Aver. 5p. & 1.00 & 0.998 & 0.95 & 0.10 \\
\hline & & $\mathrm{Al}$ & $\mathrm{Sr}$ & $\mathrm{Nd}$ & $\mathrm{Pb}$ \\
\hline $\mathrm{Sr}_{0.95} \mathrm{~Pb}_{0.05} \mathrm{NdAlO}_{4}$ & Aver. 3p. & 1.00 & 1.04 & 0.83 & 0.004
\end{tabular}

According to the local microprobe and thermogravimetric data (Table II) the mass loss in the cryochemical $\mathrm{Bi}$ - and $\mathrm{Pb}$-containing samples during the thermotreatment was determined. This phenomenon is connected with the partial $\mathrm{Pb}$ and $\mathrm{Bi}$ evaporation; $\mathrm{Pb}$-concentration decreases in about 10 and $\mathrm{Bi}-$ in 3-5 times. The samples are porous, the noticeable element segregation takes place. The oxalate samples keep an initial composition (10 at.\% Bi) and uniform element distribution. Unfortunately, single phase $\mathrm{Pb}$-containing products can be received by the oxalates precipitation: a temperature increase results in high $\mathrm{Pb}$-evaporation. 
In the case of the isovalent partial replacement in SNA of $\mathrm{Sr}$ by $\mathrm{Ba}$ $\left(\mathrm{Sr}_{1-x} \mathrm{Ba}_{x} \mathrm{NdAlO}_{4}, 0.0<x<0.5\right)$ any sample did not reach a single-phase state. In addition to the major phase SNA, X-ray reflections extra lines have been fixed on diffractogramms, the intensity of which increases with a quantity of $\mathrm{Ba}$, some of these extra lines were identified as belonging to binary aluminates $\mathrm{Sr}_{2} \mathrm{Al}_{2} \mathrm{O}_{5}$ and $\mathrm{Sr}_{4} \mathrm{Al}_{2} \mathrm{O}_{7}$. In the limits of experimental error the lattice parameters and volumes of elementary cells $\mathrm{Sr}_{1-x} \mathrm{Ba}_{x} \mathrm{NdAlO}_{4}$ did not change at the addition of $\mathrm{Ba}$, it was possible to conclude to replace strontium by barium. When $x$ exceeds 0.2 , the SNA phase does not exist any more due to the additional interactions.

The $\mathrm{ABCO}_{4}$ phase formation temperatures considerably decrease from $1500^{\circ} \mathrm{C}$ to $1000^{\circ} \mathrm{C}(\mathrm{Pb})$ and to $1200^{\circ} \mathrm{C}(\mathrm{Bi})$ by adding a small quantity of $\mathrm{Pb}$ $(\approx 0.4$ at.\%) and greater amounts of $\mathrm{Bi}(5$ and 10 at.\%) to the samples. Probably, the initial component interaction occurs without formation of intermediate aluminates.

The crystal lattice parameter misfits between the substrate materials SLA, SNA and SLG and high temperature superconductors $\mathrm{YBa}_{2} \mathrm{Cu}_{3} \mathrm{O}_{7}$ (123) and $\mathrm{Bi}_{2} \mathrm{Sr}_{2} \mathrm{CaCu}_{2} \mathrm{O}_{8}$ (2212) were calculated. Maximal misfits of lattice parameters did not exceed $4 \%$. The minimal values are observed for the gallium compound.

The electrophysical characteristics (dielectric constant $(\varepsilon)$, dielectric loss $(\tan \delta)$ and resistance $(\rho)$ ) of some synthesized materials were measured. For SLA at temperatures of 127.0-355.5 $\mathrm{K}$ the characteristic values varied in the following limits: $\varepsilon=17.14 \div 22.54, \tan \delta=0.049 \times 10^{-3} \div 0.016 \times 10^{-3}, \rho=2.72 \times 10^{12} \div$ $4.10 \times 10^{12} \Omega \cdot \mathrm{m}$. For SLG: $\varepsilon=13.11, \tan \delta=0.091 \times 10^{-3}, \rho=5.32 \times 10^{10} \Omega \cdot \mathrm{m}$.

An addition of a small excess quantity $\mathrm{Nd}_{2} \mathrm{O}_{3}(2.5 \mathrm{~mol} . \%)$ to this material did not practically change the values of the characteristics $(\varepsilon=14.75, \tan \delta=$ $\left.0.113 \times 10^{-3}, \rho=5.81 \times 10^{10} \Omega \cdot \mathrm{m}\right)$.

The complex aluminates and gallates with received dielectric and electric properties were suitable as substrates for ITSC materials.

Crystals of SLA with $\mathrm{Bi}_{2} \mathrm{O}_{3}$ were grown by the Czochralski method from an initial mixture contained 1 at. $\%$ of $\mathrm{Bi}_{2} \mathrm{O}_{3}$. The obtained crystals had a good quality and light yellow colour. The XRD and electron microprobe and chemical analysis were used to detect $\mathrm{Bi}$. The only traces of $\mathrm{Bi}$ (lower than $10^{-5} \mathrm{wt} . \%$ ) were found in the crystals. Results of XRD did not show any changes in the lattice parameters of pure SLA. The $\mathrm{Bi}_{2} \mathrm{O}_{3}$ is mainly deposited on cool parts of the growth chamber. The same results were obtained for SLG.

\section{References}

[1] Y.P. Oudalov, P.C. Salmon, I.A. Bondar, Inorg. Chem. 21, No. 2, 541 (1976).

[2] A. Dąbkowski, H.A. Dąbkowska, G.E. Greedan, J. Cryst. Growth 132, 205 (1993).

[3] D.H. Ha, Y.K. Park, J.C. Park, Jpn. J. Appl. Phys. 33, L1588 (1994).

[4] JCPDF, file 24-1125.

[5] JCPDF, file 24-1188. 